\title{
The Moira Mounds, small cold-water coral banks in the Porcupine Seabight, NE Atlantic: Part A-an early stage growth phase for future coral carbonate mounds?
}

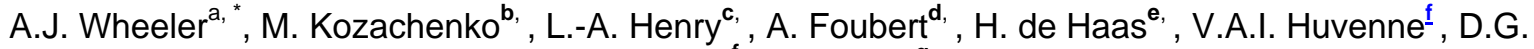 \\ Masson" and K. Olu ${ }^{\mathrm{g}}$
}

${ }^{a}$ Department of Geology \& Environmental Research Institute, University College, Cork, College Rd., Cork, Ireland

${ }^{\mathrm{b}}$ Coastal \& Marine Resources Centre, Environmental Research Institute, University College Cork, Irish Naval Base, Haulbowline, Cobh, Co. Cork, Ireland

${ }^{\mathrm{c}}$ Scottish Association for Marine Science, Oban, Argyll PA37 1QA, UK

${ }^{\mathrm{d}}$ Department of Earth and Environmental Sciences, K.U. Leuven, Celestijnenlaan 200E, B-3001

Heverlee, Belgium

${ }^{\mathrm{e}}$ Royal Netherlands Institute for Sea Research (NIOZ), PO Box 59, 1790 AB Den Burg, The

Netherlands

${ }^{\dagger}$ National Oceanography Centre, Southampton, University of Southampton, Waterfront Campus,

European Way, Southampton, SO14 3ZH, UK

${ }^{9}$ IFREMER, Centre de Brest, BP 70, 29280 Plouzané, France

* Corresponding author : A.J. Wheeler, Tel.: + 35321 4903951/1943; fax: + 35321 4271565, email

address : a.wheeler@ucc.ie

\section{Abstract:}

This paper presents a comprehensive overview of the Moira Mounds in the Porcupine Seabight, combining a review of currently published material with new data and interpretations. The Moira Mounds are circular to ovoid-shaped individual or clustered coral banks (referred to as "scleractinian spaced cluster macroreefs") located in the Belgica (carbonate) mound province, Porcupine Seabight, west of Ireland. They are up to $10 \mathrm{~m}$ high and 20 to $35 \mathrm{~m}$ in diameter. For the first time, a map showing the complete extent and location of the Moira Mounds is published, revealing 256 examples grouped into four areas mainly between 800 and $1100 \mathrm{~m}$ water depth. ROV groundtruthing revealed the importance of bedload sand transport in Moira Mound formation and development processes through sediment entrapment by coral frameworks (Lophelia pertusa and Madrepora oculata). New estimated growth rates for the Moira Mounds are comparable to those measured for much larger Irish coral carbonate mounds but an order of magnitude lower than rates from comparably sized reefs offshore Norway. As well as the framework corals, 26 macrobenthic invertebrate species were identified from a single box core that were similar to those communities found in adjacent off-mound habitats. It is proposed that the Moira Mounds are an example of the early stage growth phase of nearby giant coral carbonate mounds and represent a westward extension of the zone of active cold-water coral mound growth and therefore a deepening of the zone of cold-water coral growth over recent climate cycles.

Keywords: cold-water coral; coral carbonate mound; benthic processes; biogeological processes; marine geology; NE Atlantic 


\section{Introduction}

Cold-water coral reefs and coral carbonate mounds formed by the framework building scleractinian corals Lophelia pertusa and Madrepora oculata are common along the European continental margin at water depths from 50 to over $2000 \mathrm{~m}$ (e.g. Freiwald et al., 2004; Freiwald and Roberts, 2005; Roberts et al., 2006, 2009; Wheeler et al., 2007). Cold-water coral reefs and actively growing coral carbonate mounds exist in water masses with temperatures ranging from 4 to $12{ }^{\circ} \mathrm{C}$ (Roberts et al., 2006; Rogers, 1999), water densities of $27.35-27.65 \mathrm{~kg} \mathrm{~m}^{-3}$ (Dullo et al., 2008), preferentially in areas with fast currents (although $<100 \mathrm{~cm} \mathrm{~s}^{-1}$ : Frederiksen et al., 1992) and high surface productivity (White et al., 2005).

Cold-water coral reefs and coral carbonate mounds are triggered through initial colonisation by coral larvae on hard substrata (de Haas et al., 2009). Once established, Madrepora and Lophelia can grow on dead coral skeletal remains forming banks that rise up to $350 \mathrm{~m}$ above the seafloor and spread over several square kilometres (Roberts et al., 2009). Coral carbonate mounds are defined as "larger structures formed by successive periods of coral reef development, sedimentation, and (bio)erosion. They may or may not support contemporary reefs and are referred to as active or retired mounds, respectively" (Roberts et al., 2006, 2009). Cold-water coral reefs occurring on coral carbonate mounds support rich epifaunal communities including sponges and gorgonians (Freiwald et al., 2004; Jensen and Frederiksen, 1992; Mortensen et al., 1995; Roberts et al., 2008), provide fish habitat (Costello et al., 2005) and are subject to numerous conservation measures as high biodiversity centres (Freiwald et al., 2004).

Cold-water coral reefs and coral carbonate mounds (collectively referred to as coral banks) differ significantly in their morphology and dimensions, varying from small, low relief features a few metres high and tens of metres across, to giant mounds hundreds of metres tall and a few kilometres across (Roberts et al., 2009; Wheeler et al., 2007). Smaller coral banks include the Darwin Mounds, northern Rockall Trough, NE Atlantic (Huvenne et al., 2009; Masson et al., 2003; Wheeler et al., 2005b, 2008) and the Moira Mounds, eastern Porcupine Seabight, NE Atlantic (discussed here and also in Foubert et al., 2005; Huvenne et

al., 2005; Kozachenko, 2005; Wheeler et al., 2000, 2005c, 2007), which are semicircular to ridge-shaped in appearance and aligned to the dominant current direction. Small Lophelia reefs are also present in Norwegian waters (e.g. Freiwald et al., 2002; Hovland et al., 1998; Lindberg et al., 2007; Mortensen et al., 2001) although their morphology and shape is "inherited" from the topographic features that they colonise (Freiwald et al., 1999; Wheeler et al., 2007). Small coral banks (often referred to as bioor lithoherms in the literature) also occur on the western Atlantic margin e.g. the Savannah lithoherms on the Florida-Hatteras slope, in the Straits of Florida, in the Bahamas and in the Gulf of Mexico (Grasmueck et al., 2006; Messing et al., 1990; Reed et al., 2006; Wenner and Barans, 2001).

Over several million years (Kano et al., 2007; Sakai et al., 2009; Williams et al., 2006), repeated reef development can form coral carbonate mounds. Notably on the European margin these include the Belgica Mounds, eastern Porcupine Seabight (Beyer et al., 
2003; De Mol et al., 2002; Foubert et al., 2005; Huvenne et al., 2005; Wheeler et al., 2005c; see Figure 1A), Hovland Mounds, northern Porcupine Seabight (De Mol et al., 2002; Huvenne et al., 2002, 2005; Kenyon et al., 1998; see Figure 1A), Pelagia Mounds, northern Porcupine Bank, (Akhmetzhanov et al., 2003b; Dorschel et al., 2009; Kenyon et al., 1998, 2003; van Weering et al., 2003; Wheeler et al., 2005a; see Figure 1A) and Logachev Mounds, SW Rockall Trough (de Haas et al., 2009; Kenyon et al., 1998, 2003; Mienis et al., 2006; van Weering et al., 2003). These are predominantly current-aligned, ridge shaped features exhibiting varying degrees of contemporary biological activity. Coring suggests punctuated growth and coral settlement with sequences containing numerous hiatuses (de Haas et al., 2009; Dorschel et al., 2005, 2007b; Frank et al., 2005; Rüggeberg et al., 2005b, 2007; Sakai et al., 2009; Titschack et al., 2009; Williams et al., 2006).

In this paper, we present a review of the Moira Mounds supplemented by new data characterising the environmental context of the banks, morphological, sedimentological and biological attributes and hydrodynamic interactions. These observations are then set into context in relation to other comparable cold-water coral banks and coral carbonate mound development processes. The term Moira Mounds refers to a type of cold-water coral bank and is specific to the Belgica mound province (Figure 1A).

\section{Materials and Methods}

Surveys of the Moira Mounds were based on high resolution side-scan sonar imagery, video observations, conductivity-temperature-depth (CTD) profiles and the sampling of sedimentary sequences and benthic boundary water masses.

Side-scan sonar data were collected during RRS Discovery cruise 248 (Bett et al., 2002) using a $100 \mathrm{kHz}$ and $410 \mathrm{kHz}$ dual frequency GeoAcoustic side-scan sonar system (Figure 1) and on RV Pelagia Cruise 197 (de Haas et al., 2002) using TOBI 30 kHz sidescan sonar. Swathe width was $200 \mathrm{~m}$ at $410 \mathrm{kHz}, 600 \mathrm{~m}$ at $100 \mathrm{kHz}$ and $6 \mathrm{~km}$ at $30 \mathrm{kHz}$. All side-scan sonar data were processed using PRISM software (Le Bas and Hühnerbach, 1999) with images navigated and mosaiced based on the ship position and a layback calculation involving wire-out, wire catenation effects and inertia movement around corners. This data has been partly published previously in De Mol et al. (2007), Dorschel et al. (2007a), Huvenne et al. (2005), Kozachenko et al. (2005) and Wheeler et al. (2005c, 2007). However, new interpretations from the data revealing all the Moira Mound locations are presented here. 

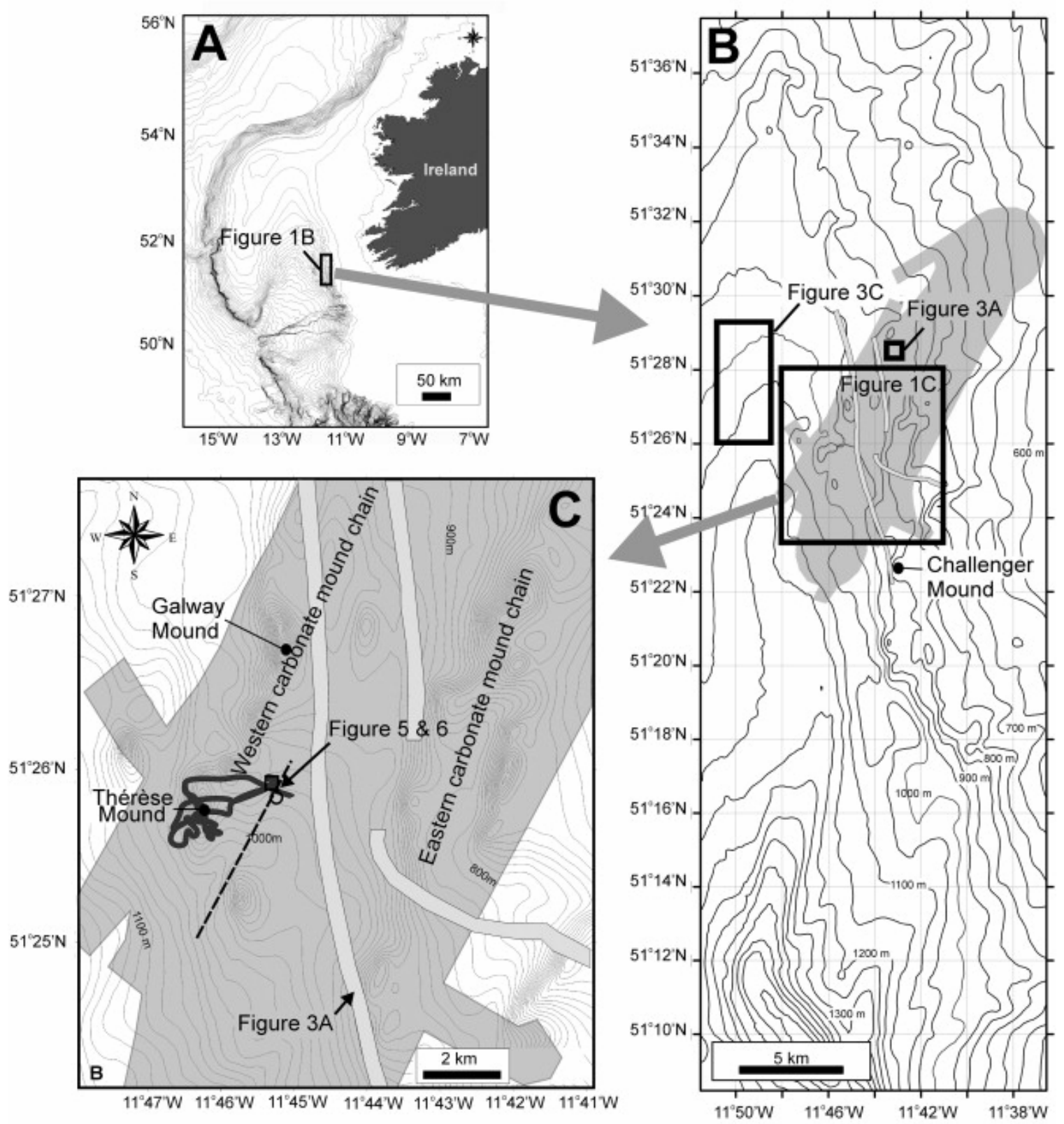

\section{Legend}

$100 \mathrm{kHz}$ side-scan sonar coverage

Combined ROV coverage

O ROV push-core CARACOLE 124-2
$410 \mathrm{kHz}$ side-scan sonar coverage

$3.5 \mathrm{kHz}$ sub-bottom profiler line

Box-core ARK XIX/3a PS64/270-1

Figure 1. Location of the Moira Mounds study area: A) location relative to Ireland, NE Atlantic, B) the first zoom image showing $100 \& 410 \mathrm{kHz}$ side-scan sonar coverage, the TOBI $30 \mathrm{kHz}$ side-scan sonar coverage is the whole zoom. The location of other figures (1C, 3A \& 3C) and the Challenger Mound are also shown, C) second zoom image showing the ROV coverage, the sub-bottom profiler line (Figure 4), sample stations and the location of figures $3 A, 5 \& 6$, the Galway and Thérèse Mounds and mound chains. Bathymetry courtesy of AWI (Beyer et al., 2002; 2003). 
Video imagery was collected using the VICTOR 6000 deep-water remotely operated vehicle (ROV) deployed from the N/O L'Atalante during the CARACOLE cruise dives 124 and 125 (Olu-Le Roy et al., 2002) and from the RV Polarstern during ARK XIX/3a (Klages et al., 2004) (Figure 1). VICTOR 6000 was equipped with up to eight camera systems giving all round coverage, two manipulator arms, an in situ methane analyser and water sampler.

VICTOR 6000 navigation was via the POSIDONIA combined ultra-short baseline and inertial navigation system and ship's differential GPS. All information including navigation, videos, video stills and scientists observations were centrally stored in the ADELIE extension for ArcGIS (CESRI) (http://www.ifremer.fr/flotte/systemes_sm/adelie/index.html) and the BIOCEAN/Alamer database (Fabri et al., 2006).

Video mosaics were made from frame grabs of the CARACOLE vertical camera data. Image overlaps were matched in PhotoShop and have been published by Kozachenko (2005), Roberts et al. (2009) and Wheeler et al. (2005c).

The VICTOR 6000 manipulator arms were used to insert $53 \mathrm{~mm}$ diameter by $400 \mathrm{~mm}$ length tubes with core-catchers into the seabed during CARACOLE dive 124-2 $\left(51^{\circ}\right.$ $25.89^{\prime} \mathrm{N} / 11^{\circ} 45.26^{\prime} \mathrm{W}$ ) (Figure 1). The sandy nature of the seabed limited the surface penetration to $5 \mathrm{~cm}$ depth with only bulk samples retrieved. Measurements of $\mathrm{pH}$, dissolved oxygen (DO), methane $\left(\mathrm{CH}_{4}\right)$ and hydrogen sulphide $\left(\mathrm{H}_{2} \mathrm{~S}\right)$ were performed on water samples collected by the VICTOR 6000 water sampling device (PEP: Préleveur d'Eau par Pompage) using standard methods (Olu-Le Roy et al., 2002).

A single $0.25 \mathrm{~m}^{2}$ spade box core was deployed following a reconnaissance survey by VICTOR 6000 from the RV Polarstern in June 2003 (site ARK XIX/3a PS64/270-1: 51 ${ }^{\circ}$ 25.96' N / $11^{\circ} 45.28$ ' W, $942 \mathrm{~m}$ water depth) (Figure 1). Upon recovery to the surface, the box core contents were photographed and the entire sample was washed through 1000, 500 and $250 \mu \mathrm{m}$ sieves with filtered seawater. The sample was stored in $10 \%$ formalin borax-buffered filtered seawater, and into industrial methylated spirit (IMS) for long-term storage and analysis. Macrofauna $(>0.5 \mathrm{~mm})$ were enumerated and identified to the lowest possible taxonomic level. Biological data from this box-core was previously published by Henry \& Roberts (2007).

Grain-size analysis was performed on bulk samples from the ROV push cores using laser diffraction techniques with a Malvern Laser Particle Sizer MasterSizer 2000 counter (MS2000). Before analysis, the calcium carbonate content was dissolved using $10 \% \mathrm{HCl}$ and the washed residue dispersed in a $10 \%$ sodium polyphosphate solution made with distilled water and shaken for 24 hours in order to achieve a perfect dispersion of all grains within the sample. Each sample was measured five times and the average result was taken to represent the sample. 


\section{Location and environmental context}

The Moira Mounds are located on the eastern margin of the Porcupine Seabight; a north-south trending basin approximately $150 \mathrm{~km}$ to the south-west of Ireland. The eastern margin also contains a number of coral carbonate mounds forming two east west mound chains at $650 \mathrm{~m}$ and $950 \mathrm{~m}$ water depth: the Belgica mound province (Beyer et al., 2003; De Mol et al., 2002; Foubert et al., 2005; Huvenne et al., 2005; Wheeler et al., 2005c) (Figure 1). Sedimentological processes on the eastern margin of the Porcupine Seabight are dominated by the presence of contourite drifts (Van Rooij et al., 2003, 2007) that onlap the coral carbonate mounds and in some cases partly bury their upslope flanks. The eastern and northern margins are also typified by a number of blind channels (Beyer et al., 2003; De Mol et al., 2002; Van Rooij et al., 2003).

Water masses on the eastern Porcupine Seabight margin, including the Eastern North Atlantic Water (ENAW) and the Mediterranean Outflow Water (MOW) which form northerly flowing contour currents as part of a cyclonic circulation system within the Seabight (Hargreaves, 1984; New and Smythe-Wright, 2001; Rice et al., 1991; Van Aken and Becker, 1996). Near the seabed, the flow is modified by "poleward flowing residual currents generated by tidal rectification processes" - that is to say northerly tidally affected contour currents (Dorschel et al., 2007a; Pingree and LeCann, 1990; White, 2007; White et al., 2007). CTD profiles in Dullo et al. (2008) for this area show an upper seasonal thermocline to $100 \mathrm{~m}$, the ENAW down to $480 \mathrm{~m}$, a transition from the ENAW to MOW down to $700 \mathrm{~m}$ and the core of the MOW down to the seabed $(990 \mathrm{~m})$.

Recent measurements of bottom currents in the Belgica mound province using a photolander demonstrated the short-term importance of tidal currents (White et al., 2007). Roberts et al. (2005) recorded peak flows of $70 \mathrm{~cm} \mathrm{~s}^{-1}$ on the summit of the Galway Mound (Figure 1) with residual flows of $13.6 \mathrm{~cm} \mathrm{~s}^{-1}$ to the northwest that intensify to $>50 \mathrm{~cm} \mathrm{~s}^{-1}$ during peak spring tides. Similar values were also monitored by Dorschel et al. (2007a), from a nested multi-deployment of current meters over the Galway Mound, where the dominance of east-west tidal flows and north-westerly residual flows were also reported. Maximum currents speeds on the mound summit were $51 \mathrm{~cm} \mathrm{~s}^{-1}$ with mean speeds ranging from $16 \mathrm{~cm} \mathrm{~s}^{-1}$ (summit) to $6 \mathrm{~cm} \mathrm{~s}^{-1}$ (southern flank). Current intensification caused by the interaction of the current flow with the local topography suggests that southern flank values may be more typical for the Moira Mounds.

Benthic water mass chemical properties were measured at the base and summit of a Moira Mound (Olu-Le Roy et al., 2002). These revealed typical pH values (7.8) and dissolved oxygen (DO) estimates that decreased from the base $\left(6.4 \mathrm{ml} \mathrm{I}^{-1}\right)$ to the summit of the mound $\left(4.4 \mathrm{ml} \mathrm{l}^{-1}\right)$, implying on-mound biological productivity stimulating high biological oxygen demand (BOD). Negligible concentrations of $\mathrm{CH}_{4}\left(<0.05 \mu \mathrm{M} \mathrm{1^{-1 }}\right)$ and $\mathrm{H}_{2} \mathrm{~S}$ were also recorded. 


\section{Moira Mound distribution}

The Moira Mounds occur within the Belgica mound province mainly between the two coral carbonate mound chains (mid-slope area) and within a blind north-south orientated channel immediately west (downslope area). Figure 2 shows the locations of 256 Moira Mounds identified on the 30, 100 and $410 \mathrm{kHz}$ side-scan sonar within an area of 700 $\mathrm{km}^{2}$. All identified banks appear as positive relief features of comparable size and signature to those groundtruthed. The size of the features means that those identified on $30 \mathrm{kHz}$ TOBI data are "probable Moira Mounds" (176 banks) as best assessed based on the resolution of the side-scan sonar (Figure 4c) whereas those on $100 \mathrm{kHz}$ and $410 \mathrm{kHz}$ are definite Moira Mounds (80 banks) (Figure $4 a$ and b). Seven of the Moira Mounds imaged have been groundtruthed by ROV (Foubert et al., 2005; Klages et al., 2004; Kozachenko, 2005; Olu-Le Roy et al., 2002; Wheeler et al., 2005c) (see section 5.2) and box-cored (Klages et al., 2004; Kozachenko, 2005) (see section 6 and 7). 

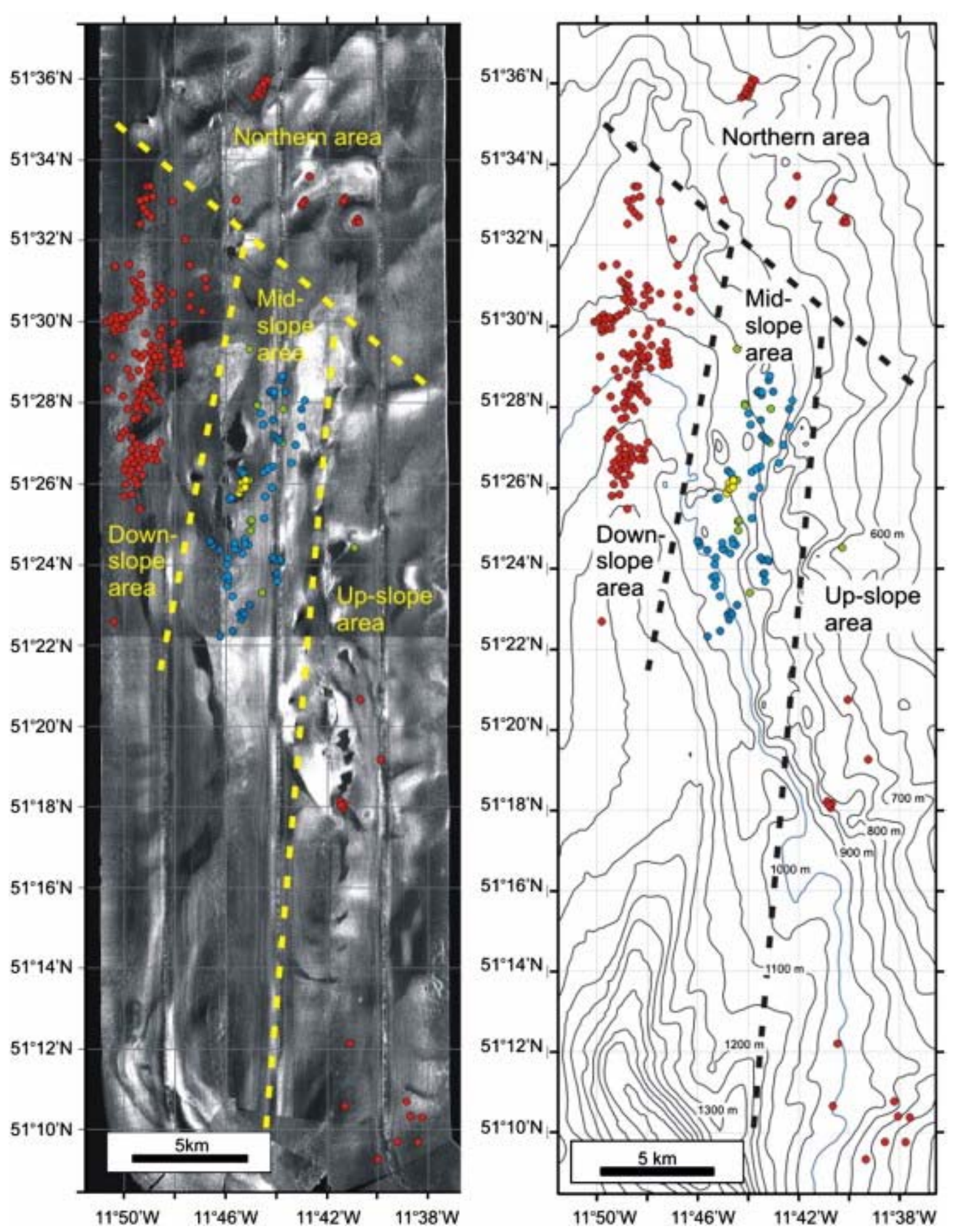

Figure 2. (COLOUR VERSION) $30 \mathrm{kHz}$ side-scan sonar (TOBI) mosaic showing the location of identified Moira Mounds and coral carbonate mounds. Dashed line divides the 4 areas (see text). Red dots = identification based on $30 \mathrm{kHz}$ side-scan sonar data; blue dots = identification based on $100 \mathrm{kHz}$ side-scan sonar data, green dots = identification based on $410 \mathrm{kHz}$ side-scan sonar data; yellow dots = groundtruthed by ROV and identified on 100 and $410 \mathrm{kHz}$ side-scan sonar; black ellipses = coral carbonate mounds aligned in eastern and western chains. 
Figure 2. (BLACK \& WHITE VERSION) $30 \mathrm{kHz}$ side-scan sonar (TOBI) mosaic showing the location of identified Moira Mounds. Dashed line divides the 4 areas (see text). White dots = identification based on $30 \mathrm{kHz}$ side-scan sonar data; black dots = identification based on $100 \mathrm{kHz}$ side-scan sonar data, white dots with black outlines = identification based on $410 \mathrm{kHz}$ side-scan sonar data; black dots with white outlines = groundtruthed by ROV and identified on 100 and $410 \mathrm{kHz}$ side-scan sonar. Black outlines ellipses = coral carbonate mounds aligned in eastern and western chains.

The compilation of a complete Moira Mounds distribution allows the Belgica mound province to be divided into four areas of Moira Mounds for the first time based on common geographic and bathymetric attributes; a northern area, an upslope area, a mid slope area and a downslope area.

The northern area contains 20 Moira Mounds within a depth range of 700 and $800 \mathrm{~m}$ water depth. These Moira Mounds occur in four clusters of two, three, four and ten, with one isolated bank. All the bank clusters occur on the summits of rises with the exception of the cluster of three that is found half way up the flank of a rise and a cluster of ten Moira Mounds within a channel.

The upslope area covers a wider depth range occurring between 650 and $1000 \mathrm{~m}$ water depth. 15 examples are identified upslope of the most eastern chain of coral carbonate mounds that includes the Challenger Mound drilled during IODP Exp. 307 (Foubert et al., 2005; Williams et al., 2006) (Figure 1). These coral carbonate mounds are "dormant" with limited contemporary coral colonisation (Foubert et al., 2005). With the exception of one cluster of four Moira Mounds, the up-slope Moira Mounds are all isolated examples occurring on both slopes and flat-lying areas. Eight of the Moira Mounds in the south of the area occur as isolated examples between 750 and $1000 \mathrm{~m}$ water depth at the depth range were most of the live coral has been observed and most of the Moira Mounds occur.

The mid-slope area is located between the eastern and western chains of coral carbonate mound (between 850 and $1100 \mathrm{~m}$ water depth). The western chain of coral carbonate mounds are "active" (Foubert et al., 2005) with dense coral coverage e.g. the Galway (Dorschel et al., 2007a) and Thérèse Mounds (De Mol et al., 2007) (Figure 1). There are 78 examples of Moira Mounds occurring as isolated banks and clusters between these larger carbonate mound chains. The banks occur on sediment plains typified by ripple sands or at the head (up-current) of sediment wave fields or ridges and furrows (Foubert et al., 2005; Wheeler et al., 2005c; Foubert et al., this issue) (see figure 4a). This area of banks includes examples imaged at the highest resolution side-scan sonar (410 kHz) (Figure 4b), inspected by ROV and sampled (Klages et al., 2004; OluLe Roy et al., 2002). One cluster of banks is visualized by ROV-borne high-resolution multibeam bathymetry and discussed by Foubert et al., this issue. 

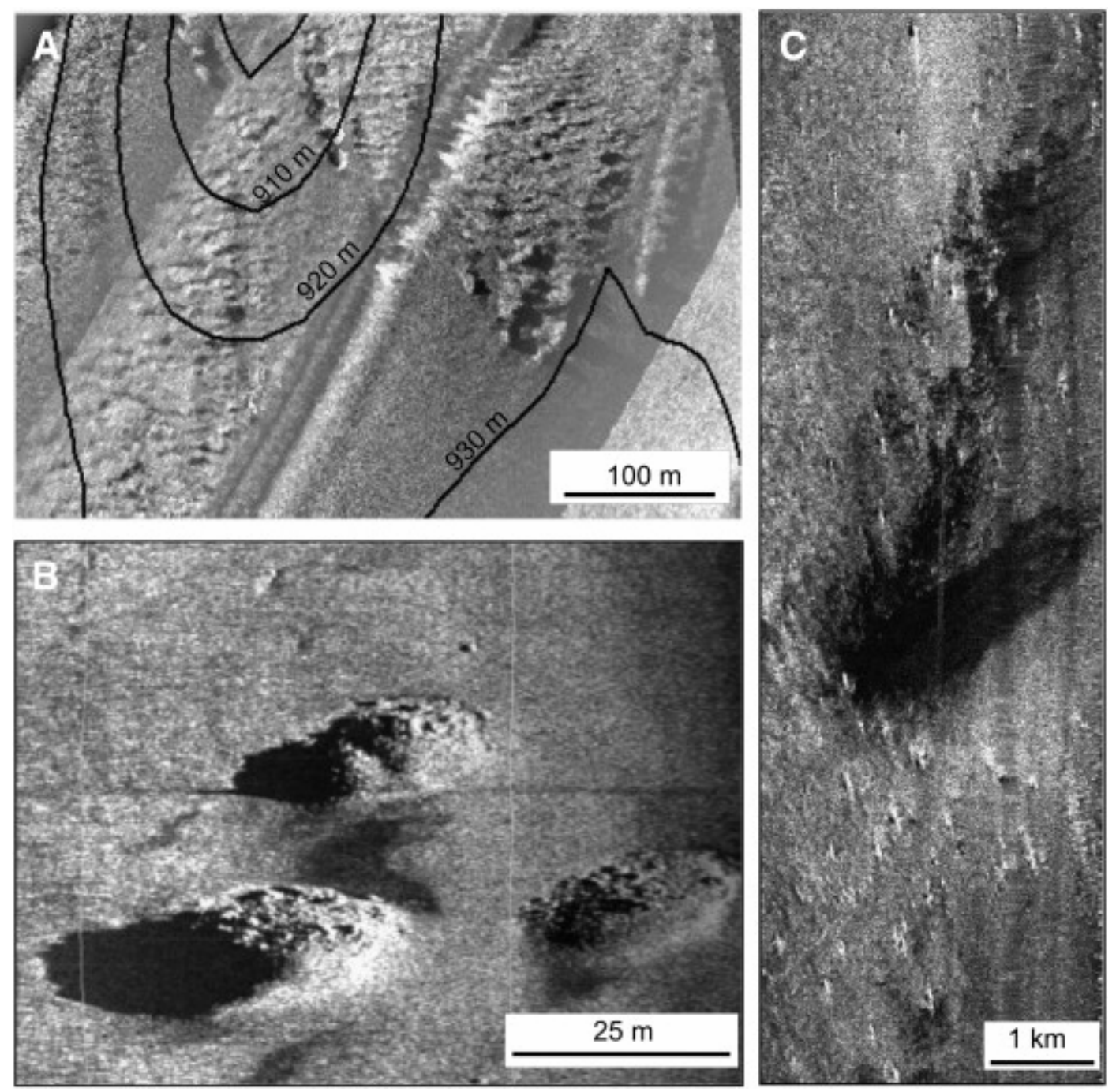

Figure 3. Side-scan sonar images of Moira Mounds: A) $100 \mathrm{kHz}$ image showing Moira Mounds at the up-stream edge of sediment wave field from the mid-slope area (bathymetric contours every $10 \mathrm{~m}$ ), B) $410 \mathrm{kHz}$ image of three Moira Mounds from the mid-slope area (image inverted, acoustic shadows are black) (after Wheeler et al., 2005c), and C) $30 \mathrm{kHz}$ (TOBI) image showing a cluster of Moira Mounds from the downslope area.

The downslope area of Moira Mounds lies below 900 down to $1150 \mathrm{~m}$ water depth beyond the downslope limit of coral carbonate mounds. The banks were noted by Wheeler et al. (2003) and Huvenne et al. (2005) (see Figure 4c). There are 143 examples of mounds identified from $30 \mathrm{kHz}$ side-scan sonar only. Banks typically occurred as part of large widely-spaced clusters. The banks occur in a flat-lying area that is the base of a blind channel (Beyer et al., 2003; Huvenne et al., 2005; Van Rooij et al., 2003). 


\section{Mound Morphology}

\subsection{Gross morphology}

Low resolution side-scan sonar imagery reveals the Moira Mounds as clearly defined, high backscatter banks with steep sides. They are ovoid in shape measuring between 20 and $35 \mathrm{~m}$ in diameter with their long-axis orientated parallel to the residual current flow direction (Fig $3 \mathrm{a}-\mathrm{c}$ ). Figure 4b shows a high resolution $410 \mathrm{kHz}$ image of three domeshaped Moira Mounds revealing that the high backscatter shows a degree of variation. Video groundtruthing (Figures 5 and 6-) of other Moira Mounds suggests that this corresponds to areas of coral colonies (high backscatter) and sandy sediment (low backscatter) comparable with similar findings in the Darwin Mounds (Masson et al., 2003; Wheeler et al., 2008). Estimates based on sub-bottom profiler data (Figure 4) and acoustic shadows cast by the Moira Mounds (e.g. Figure $3 b$ ) suggest heights within the range of three to $11 \mathrm{~m}$ tall. Bank slope gradients are estimated at $20^{\circ}$ (Figure 4 and 5A).

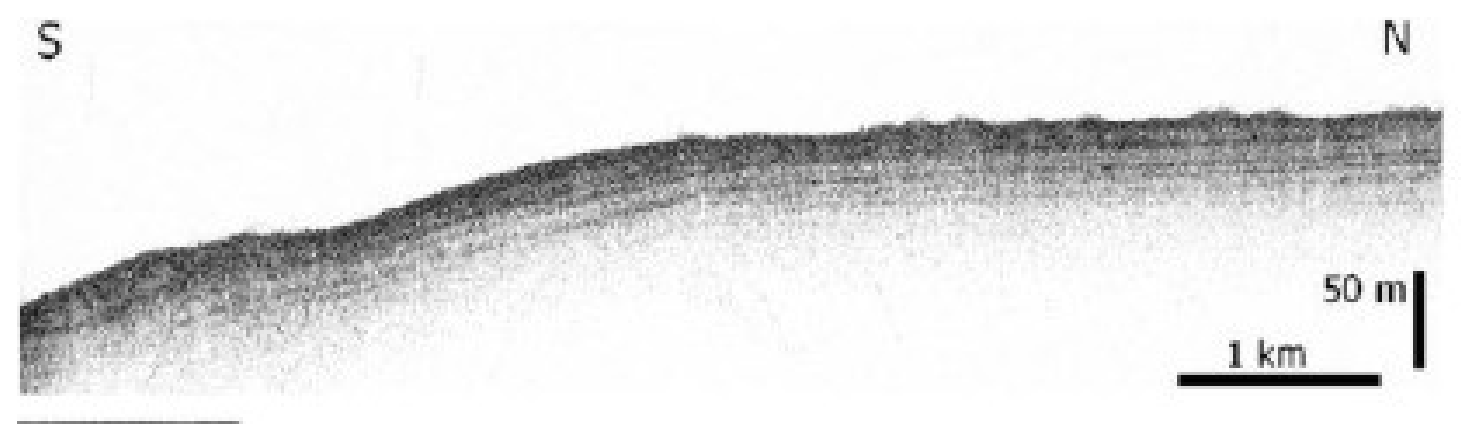

Figure 4. $3.5 \mathrm{kHz}$ sub-bottom profiler image showing Moira Mounds on stratified sediment with no sub-surface expression suggesting they are geologically recent (after Huvenne et al., 2005). 

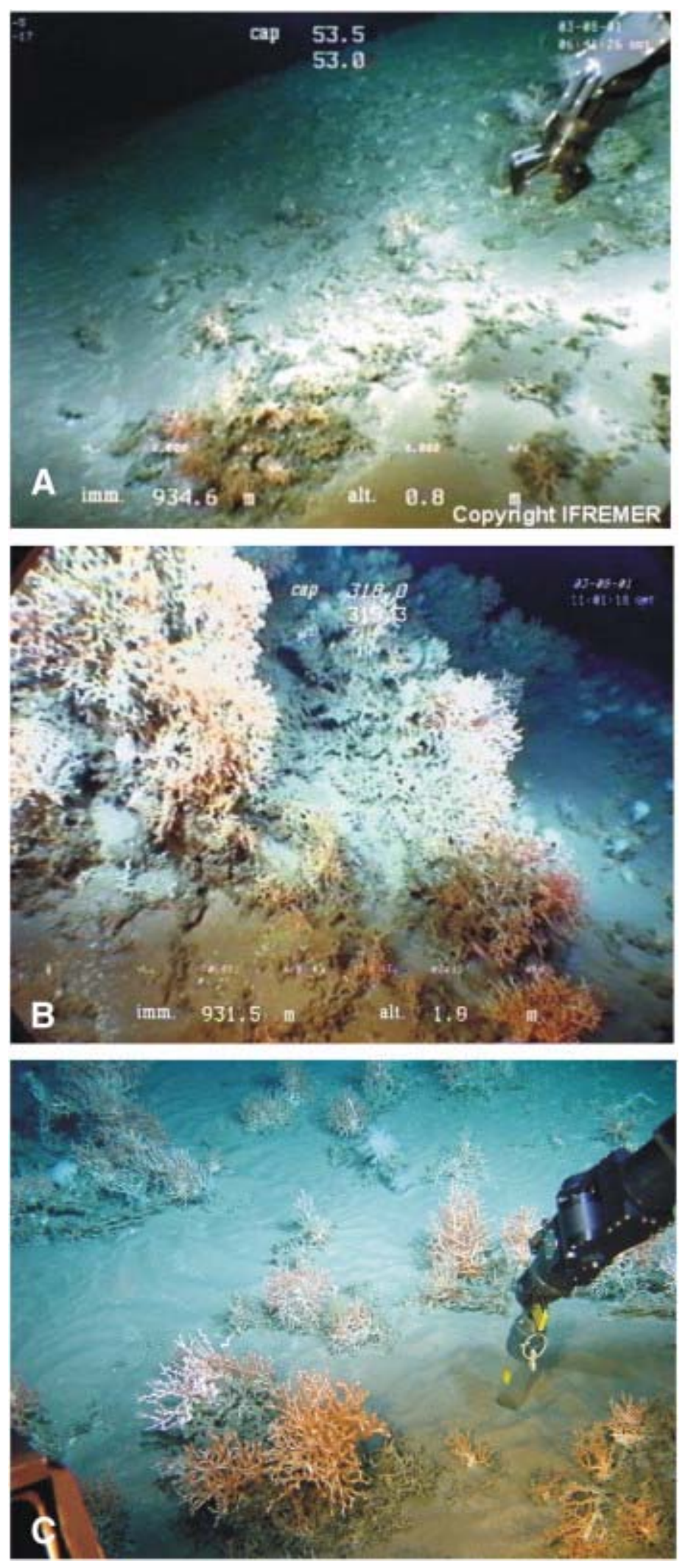

Figure 5. A) ROV image of the base of a Moira Mound showing the slope angle of $20^{\circ}$ (after Wheeler et al., 2005c), B) The summit of a Moira Mound at the site of box core 
PS64 270/1 showing large colonies of Madrepora occulata, C) ROV image form within a Moira Mound showing Lophelia pertusa, Madrepora oculata and sponge Aphrocallistes bocage growing in rippled sands at the on-bank ROV push core site.

The more northerly bank on Figure $4 b$ has two summits that may have formed as a result of either the coalition of two banks or heterogeneous growth, which is again comparable to similar observations from the Darwin Mounds (Wheeler et al., 2008).

Sub-bottom profiler data (Figure 4) also show that the Moira Mounds are surficial features with no sub-surface expression (Huvenne et al., 2005). This suggests that the Moira Mounds are, in geological terms, relatively young and possibly Holocene (Foubert et al., 2005; Huvenne et al., 2005).

\subsection{Surface morphology}

Seven Moira Mounds located to the east of Thérèse Mound were investigated using the ROV (Figure 2). The surface appearance of a Moira Mound near its summit at $932.5 \mathrm{~m}$ water depth is shown in Figure 5B revealing metre-high coral colonies interspersed with areas of sand (Foubert et al., this issue). Dead coral frameworks can also be seen protruding from the sand cover providing attachment points for the live corals and sponges. A photo mosaic of frame grabs from the vertical camera over another Moira Mound summit is shown in Figure 8a. Coral colonies account for, on average, $40 \%$ of bank cover: varying from small, isolated, decimetre colonies accounting for $20 \%$ of cover to metre scale colonies covering $70 \%$ of the bank surface. Areas between coral colonies consist of exposed sand and dead coral frameworks. 

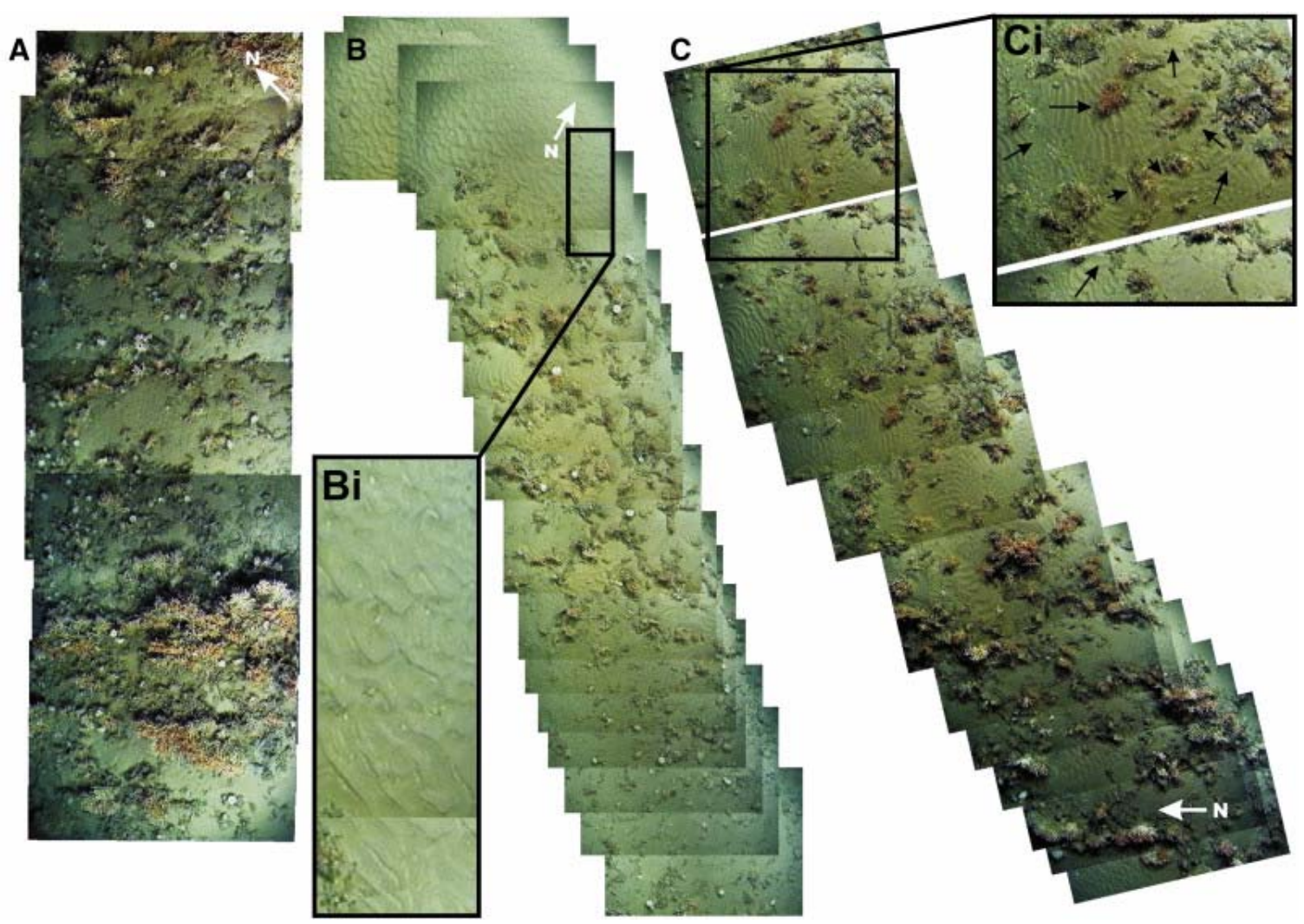

Figure 6. A) Video-grab photo mosaic from the summit area of a Moira Mound. B) Videograb photo mosaic showing the off-bank to on-bank transition. Bi) insert showing transition from sinuous to straight crested ripples as current speeds decrease entering the bank C) Video-grab photo mosaic showing complex bedload transport / coral colony interaction from the flank of a Moira Mound. Ci) detail of current sediment interactions with arrows showing sediment transport directions (from Kozachenko, 2005).

The transition from off-bank areas onto the bank is shown in Figure 8b. Here, the lower flanks of the bank reveal 30\% coral cover, with the sponge Aphrocallistes bocagei and large coral colonies absent. Immediately off-bank, areas are characterised by sinuous crested ripples implying active sediment bedload transport (Figure 8bi). On-bank, current speeds decrease to produce straight-crested rippled and planar beds (Figure 8bi) (Foubert et al., this issue). The influence of corals on current flow and resultant smaller scale bedforms is particularly well shown in Figure 8c and ci from the bank flanks. Current flow is impeded by the obstruction of the coral colonies with ripple crests being curved due to variations in current speeds (from adjacent to colonies, to in between colonies). The coral colonies also produce a complex eddy flow over the bank with ripple orientation suggesting bedload transport in various directions. 


\section{Moira Mound Sedimentology}

Figure 7 shows the grain-size distribution of the bulk sediment samples from the top 5 $\mathrm{cm}$ of a sediment profile at two ROV push core sites: Dive 124-2/Sample 1 - immediately off-bank core and Dive 124-2/Sample 2 - on-bank core (Figure 5C) (Olu-Le Roy et al., 2002). Both samples show well sorted sands, although the off-bank sample is slightly less well sorted. Mean grain-size for the on-bank sample is $250 \mu \mathrm{m}$. The sand of the offbank sample is slightly coarser at $400 \mu \mathrm{m}$.

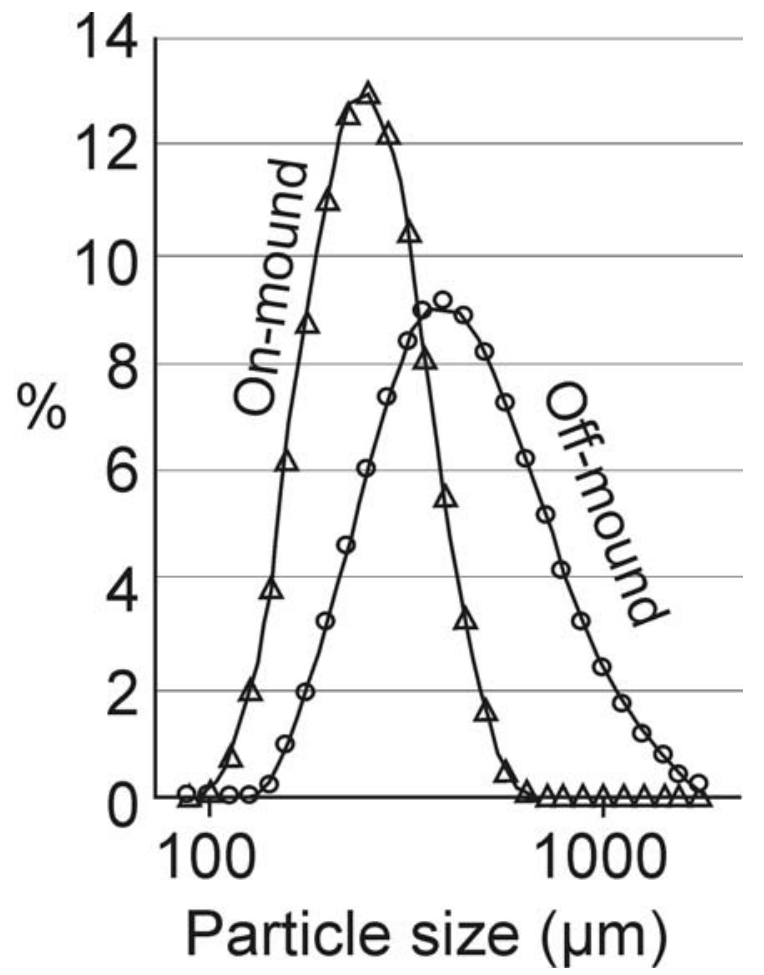

Figure 7. Grain-size distribution for both off-bank and on-bank samples.

\section{Moira Mound Biology}

Video coverage of the Moira Mounds (Figures $5 \& 6$ ) reveals conspicuous megafauna at the bank summit, including scleractinians (Madrepora oculata and Lophelia pertusa), and the large hexactinellid sponge Aphrocallistes bocagei (synonym $A$. beatrix). Smaller coral colonies are also present on the flanks down to the bank base. These megafauna are not unique to the Moira Mounds and are typical of many carbonate mounds 
throughout the Belgica mound province (Foubert et al., 2005: Henry and Roberts, 2007). The other taxa observed on video and photos were also abundant on the nearby Thérèse Mound, such as unidentified actinarians, the regular echinoid Cidaris cidaris, the crab Paromola cuvieri, and fishes observed elsewhere on coral banks and in sediment areas around the banks, including the Moridae Lepidion eques and Mora moro and Phycis blennoides and some anguiliforms (P. Lorance, pers. identification)

A single spade box-core at the summit of one of the Moira Mounds (ARK XIX/3a PS64/270-1, Klages et al., 2004) contained 26 macrobenthic invertebrate species across seven phyla (Table 1; also see Henry and Roberts, 2007 for species list, which has since been taxonomically refined). The most speciose taxa were hydroids (6 species), polychaetes (4 species, including one new to science) and bryozoans (3 species, including one new to science). The hydroids were typically smaller $(<10 \mathrm{~mm})$ macrobenthic species found living epibiotically on the Lophelia and Madrepora fragments/rubble, but the larger more robust hydrocoral Pliobothrus symmetricus was one exception. Three out of four of the polychaete species found in this box core (Lumbrineris tetraura, Lysidice nov. sp. and Procerea sp.) belonged to families that are typically associated with corals, hydroids and bryozoans, as these taxa frequently use sessile epifauna for shelter or as prey (Martin and Britayev, 1998). Bryozoans were all erect cyclostome species, and were found mainly on coral fragments/rubble. The community in this sample was closely similar in species composition to those found in off-bank areas of the Belgica mounds (Henry and Roberts, 2007). Interestingly, the small epibiotic hydroid Garveia grisea was found on the Moira Mounds, and previously only thought to occur in shallow Mediterranean waters.

TABLE 1. Macrofaunal species collected by box core at station PS64/270-1. Species names are as in Henry and Roberts (2007).

\begin{tabular}{|l|}
\hline Porifera \\
\hline Hexactinellida \\
\hline Aphrocalliistes bogagei (Schulze, 1886) \\
\hline Cnidaria \\
\hline Hydrozoa \\
\hline Eudendrium sp. \\
\hline Garvia grisea (Motz-kossowska, 1905) \\
\hline Halecium Tenellum Hincks, 1861 \\
\hline Lafoeina tenuis G.O. Sars, 1874 \\
\hline Pliobothrus symmetricus Pourtalès, 1868 \\
\hline Sertularella tenella ( Alder, 1856) \\
\hline
\end{tabular}




\begin{tabular}{|l|}
\hline Scleractinia \\
\hline Lophelia pertusa (Linnaeus, 1758) \\
\hline Madrepora oculata (Linnaeus, 1758) \\
\hline Scyphozoa \\
\hline Coronatae sp. \\
\hline Mollucea \\
\hline Bivalvia \\
\hline karnekampia Sulcata (O.F. Muller, 1776) \\
\hline Delectopecten vitreus (Gmelin, 1791) \\
\hline Gastropoda \\
\hline ?Clio sp. \\
\hline Annelida \\
\hline Polychaeta \\
\hline Lumbrineris tetraura (Schmarda. 1861) \\
\hline Lysidice nov. sp. \\
\hline Paraonidae sp. \\
\hline Proceraea sp. \\
\hline Nematoda \\
\hline Adenophores \\
\hline Cylicoliamis of magnus (Villot, 1875) \\
\hline Synonehus of acuticaudata (Jägerskjöld, 1901) \\
\hline Bryozoa \\
\hline Bryozoa sp. \\
\hline Cyclostomatida \\
\hline Crisia nov. sp. \\
\hline Cyclostomata sp. \\
\hline Tubulipora penecillata (O. Fabricius, 1780) \\
\hline
\end{tabular}




\begin{tabular}{|l|}
\hline Crustacea \\
\hline Malacostraca \\
\hline Amphipoda sp. \\
\hline Malacostraca sp. \\
\hline Unknown \\
\hline Unknown sp. \\
\hline
\end{tabular}

\section{Discussion}

\subsection{What are the Moira Mounds?}

The Moira Mounds are biogeological constructs composed predominantly of well sorted sand with subordinate biological components supported by a calcareous coral framework of Lophelia pertusa and Madrepora oculata. Many terms, often confusingly, have been proposed for such coralligenic features including carbonate mounds, bioherms, lithoherms, coral banks, coral mounds and reefs (Roberts et al., 2009). Moira Mounds should not be classified as coral carbonate mounds as there is no evidence of successive coral reef formation. Coral banks (De Mol et al., 2002), defined as positive topographic features associated with coral, is a general unambiguous term applicable in this context.

More specifically, Rogers (1999) refers to features such as the Moira Mounds as reefs based on their physical and biological characteristics with Roberts et al. $(2006,2009)$ applying the term biological reefs. Riding (2002) provides a structural classification of organic reefs and carbonate mud mounds, with the Moira Mounds fitting the definition of cluster reefs as "skeletal reefs in which essentially in place skeletons are adjacent, but not in contact, resulting in matrix support; characterised by relatively high matrix/skeleton ratios and low volumes of extra-skeletal early cement. Sediment trapping is an important corollary of skeletal growth and cluster reef organisms are tolerant of loose sediment". More specifically, Riding (2002) proposes the appropriate sub-definition of scleractinian spaced cluster macroreefs: "buildups formed by scleractinian corals between $10 \mathrm{~m}$ and less than $100 \mathrm{~m}$ across where coral skeletons are more than one, and up to two unitdistances apart".

The Moira Mounds are here defined as "cold-water coral banks" but can more specifically be referred to as "scleractinian spaced cluster macroreefs". The name "Moira Mound" refers to this type of bank that is common in, and specific to, the Belgica mound province.

8.2 The Moira Mounds within the context of other regional cold-water coral banks 
Biologically, the Moira Mounds are dominated by epifaunal suspension-feeders, which is perhaps not surprising given the fast bottom currents implied by the occurrence of rippled sand sheets developed within the sediment wave field (Wheeler et al., 2005c) and the proximity of the "active" Thérèse Mound (Figure 1) where these taxa also dominated. Nevertheless, the influence of active sand transport through the Moira Mounds resulted in greater affinities in the Moira Mound fauna to off-bank fauna, as opposed to that of the Thérèse or Galway Mound (Figure 1) communities (Henry and Roberts, 2007).

Henry and Roberts (2007) compared the macrobenthic communities of the box-core sampled Moira Mound site presented here with samples from coral carbonate mound sites (Thérèse and Galway Mounds) and adjacent off-bank sites. Although this is difficult to state with only one box core sample due to the heterogeneity of this habitat, the similarity of species occurrences between the Moira Mound and areas off-bank (Fig. 8 in Henry and Roberts, 2007) is notable, as this evidence can be used to support the idea of a recent initiation of bank formation. The species that occur on the Moira Mounds simply reflect those from the local fauna who have colonised the banks to date, and thus these species are not unique to these bank features and distinctly different from the older developed coral carbonate mound faunas. Of particular interest is the ubiquitous presence of the epilithic hydrocoral Pliobothrus symmetricus on both the Moira Mounds and the adjacent off-bank areas. Hydrocoral distribution is inversely related to the distribution of other spatial competitors including scleractinian corals (Cairns, 1992; Tendal et al., 2005). Nevertheless, large size mobile fauna (echinoderms, crustaceans, fishes) show common species with the larger mounds, although the species richness is lower. While both Madrepora oculata and Lophelia pertusa presently occur on the Moira Mounds, the density and extent of coral cover, and the size of the coral colonies notably at the summits of the banks, is much less than that seen on nearby coral carbonate mounds (Dorschel et al., 2007a). It may then be expected that as the Moira Mounds develop, hydrocoral occurrence may be reduced concurrently alongside scleractinian coral growth and mound development. Furthermore, with increased vertical growth of the Moira Mounds over time and a resulting increased occurrence and diversity of microhabitats on the banks, a corresponding increase in species richness on the Moira Mounds could also be expected, which could eventually rival that of the giant contemporary coral carbonate mounds.

As well as biological differences between the banks, the sedimentary environment of the Moira Mounds is clearly different to that of the coral carbonate mounds in the Belgica mound province (Foubert et al., this issue). Coral carbonate mound summits are up to $280 \mathrm{~m}$ higher in the water column than the Moira Mounds, tend to have a denser and thicker coral cover (De Mol et al., 2007; Dorschel et al., 2007a) and exist at the upper boundary of the same water mass (Mediterranean Outflow Water). Isolated from benthic bedload transport and receiving more limited hemipelagic and bedload sediment inputs, inter-colony areas are composed of coral rubble and dead coral framework.

A potentially comparable bank setting, and certainly comparable water depth, can be found at the base of the coral carbonate mounds in the western chain where dense coral stands coincide with significant sand-sized bedload transport in the benthic boundary layer; notably the well studied Thérèse and Galway Mounds (De Mol et al., 2007; 
Dorschel et al., 2007a; Foubert et al., 2005; Wheeler et al., 2005c). However, bedload transport at the base and lower flanks of the coral carbonate mounds results in a different growth form with an absence of small coral banks being replaced by elongated ridges of coral with active coral growing on the crests of the ridges (De Mol et al., 2007; Foubert et al., this issue; Huvenne et al., 2005; Wheeler et al., 2005c, 2007). These bedforms are superficially similar to sediment waves although slightly steeper (Foubert et al., this issue), non-mobile and composed of matrix supported coral.

The Darwin Mounds, northern Rockall Trough, offshore NW Scotland (Huvenne et al., 2009; Masson et al., 2003; Wheeler et al., 2005b, 2008) are approximately twice the size (c.50 $\mathrm{m}$ in diametre) of the Moira Mounds but in other ways are remarkably similar. Both types of banks possess sandy interstitial sediments, show a comparable internal arrangement of coral communities, baffle sediment, are influenced by hydrodynamic conditions and exist (in some cases) on the edge of sediment wave fields (Huvenne et al., 2009; Wheeler et al., 2008). This implies comparable hydrodynamic controls on bank growth (see below). The dimensional differences may be due to fundamental differences in bank genesis. The Darwin Mounds are proposed as coral-colonised fluid escape structures that provide a suitable firm substrate for coral colonisation (Masson et al., 2003). The overall dimensions of the Darwin Mounds may therefore be based on the inherited dimensions of the fluid escape structures. Once the banks are established, sediment supply by benthic currents affects bank morphology and contributes to enhance growth rates by providing sediment which becomes trapped within the coral cover (Wheeler et al., 2008). An increase in bank elevation and downstream elongation has been quantified with respect to inferred sediment flux (Wheeler et al., 2008). Downstream elongation is also noted in the Moira Mounds (Figure 4a-c).

Biodiversity comparisons between the Darwin Mounds and the Moira Mounds demonstrate a richer macrofauna on the former, which is highly dissimilar in species composition from the latter. The Darwin Mound macrofauna is characterised by serpulid polychaetes (chiefly Serpula vermicularis), brachiopods (likely Platidia anomioides), encrusting sponges (chiefly Ascaltis lamarcki) and ophiuroids (chiefly Ophioscolex glacialis) (Henry and Roberts, 2004; Wheeler et al., 2005b). Also notable are large megafaunal xenophyophores, probably Syringammina fragilissima (Hughes and Gooday, 2002), and large Lophelia pertusa colonies encrusted with epifauna (Henry and Roberts, 2004) and the large eunicid polychaete Eunice norvegica, a species that is closely associated with the Lophelia pertusa skeletal framework (Roberts, 2005). The absence of the hydrocoral Pliobothrus symmetricus, despite its occurrence in adjacent areas (Henry and Roberts, 2004), is notable and could signify a threshold occurrence of spatial competitors such as Lophelia pertusa. Thus, the larger size of the Darwin Mounds, their richer macrofauna, the lack of hydrocorals and the presence of known "symbiotic" associates on the Darwin Mounds relative to the Moira Mounds suggests that former may represent the prospective biological state of the latter over time.

\subsection{Moira Mound initiation, growth and future potential}

Two main questions have dominated geobiological research into cold-water coral banks from the beginning: how do they form and how do they grow? Bank genesis has been attributed to hydrocarbon seepage (Henriet et al., 1998; Hovland, 2008; Hovland and 
Thomsen, 1997; Hovland et al., 1994; Le Guilloux et al., 2009) with analogies drawn to cold seeps (Sibuet and Olu, 1998). However, this remains speculative with, as yet, no direct supporting evidence for this hypothesis. In situ methane measurements from benthic water on the summits of a Moira mound gave negligible results $\left(<0.05 \mu \mathrm{M} \mathrm{I}^{-1}\right.$ : see section 3). Furthermore, no evidence was found of microbial mats, exaerobic fauna or carbonate crusts characteristic of active cold seeps. This suggests that bank growth may be dependent on hydrodynamic processes.

Substantiated evidence shows that individual coral colonies settle on hard substrata (e.g. dropstones, hardgrounds, dead coral frameworks or man-made structures) and thrive under appropriate environmental conditions (e.g. Freiwald et al., 1999; Roberts, 2002; Roberts et al., 2006; Wheeler et al., 2005c). On the eastern margin of the Porcupine Seabight, increases in the rate of ocean circulation since the last glaciation have resulted in increased basal current velocities relative to those experienced during glacial times (Van Rooij et al., 2007). As a result, many areas of the seafloor have experienced non-deposition or erosion exposing hard substrata, such as dropstones, which form suitable substrates for coral colonization (Foubert et al., 2005, this issue; Wheeler et al., 2005a).

A lack of long core material penetrating the Moira Mounds has precluded the opportunity to make definitive statements about bank initiation. However, sub bottom profiler records confirm that, unlike the Belgica Mounds, Moira Mounds are confined to the upper sedimentary units with no significant sub-surface reflections (Huvenne et al., 2005). An assessment of ROV-based high resolution multibeam data suggests that the groundtruthed Moira Mounds were initiated on a series of relict mud/clay ridges as part of a ridge-furrow system (Foubert et al., this issue). Foubert et al. (this issue) speculate that these ridges were formed by late glacial/deglacation intensification of benthic currents that eroded glacial sediments and thus creating both the ridges and potential exposing dropstone that could be colonised. This implies that the Moira Mounds are potentially a Holocene feature and if so have reached heights of $10 \mathrm{~m}, 3 \mathrm{~m}$ on average, in $10 \mathrm{ka}$ producing an previously unpublished average bank growth rate of $0.3 \mathrm{~mm} \mathrm{\textrm {a } ^ { - 1 }}$. The possibility is reserved that the banks may not have started growth at 10 ka but later, perhaps at 8 ka comparable to Norwegian reefs (Freiwald et al, 1999; Lindberg et al., 2007). If so then Moira Mound growth rates would be higher at $0.375 \mathrm{~mm} \mathrm{a}$. These rates are still an order of magnitude below the documented Norwegian reef growth rates, e.g. the Sula Ridge, $4.3 \mathrm{~mm} \mathrm{a}^{-1}$ (Freiwald et al, 1999) and the Fugløy Reef, $5 \mathrm{~mm} \mathrm{a}{ }^{-1}$ (Lindberg et al., 2007), and may imply that the corals are stressed, possibly due to the high levels of sand transport (Foubert et al., this issue). Documented bank growth rates from coral carbonate mounds from the Porcupine Seabight are of the same magnitude (0.067-0.5 mm a $\mathrm{m}^{-1}$; Dorschel et al., 2007b; Frank et al., 2005; Kano et al., 2007; Titschack et al., 2009). Although these are averaged over longer time periods spanning reef growth and mound erosional stages, the Moira Mounds' growth rates seem to imply that rates of reef growth in the Porcupine Seabight are considerably slower than those on the Norwegian Shelf where we see reefs reaching up to $35 \mathrm{~m}$ high within 8000 years (Freiwald et al., 1999). The rate of growth of the coral banks may therefore be more related to regional factors rather than the stage of development. 
The estimated growth rate for the Moira Mounds is speculative. Interestingly, if we assume that the growth rate of the Moira Mounds was comparable to those of Norwegian reefs then we can calculate an initiation date of 600 to $700 \mathrm{BP}$, at the start of a slightly less pronounced but significant shift in European climate, the so-called Little Ice Age (1300 to 1850 AD) (Fagan, 2000).

It has been noted that the transition from isolated colonies to coral banks occurs as corals cause the current flow to slow down due to frictional drag thus encouraging sand deposition (Roberts et al., 2009; Wheeler et al., 2008). This effect is evident on the Moira Mounds (Figure $8 \mathrm{~b}$ and $\mathrm{c}$ ) where ripples change from sinuous crests (off-mound) to straight crested (on-mound) indicative of reduced flow conditions (Roberts et al., 2009). Furthermore, ripple crests are wider spaced, showing a greater migration rate, between coral colonies reinforcing the concept that coral colonies are responsible for current retardation (Figure 8c). Assessment of the direction of sediment movement on the banks also shows the influence of eddy fields which may assist in the retention of sand on the bank (Figure 8c). Furthermore, as sediment accumulates around the coral it may provide a physical support thus encouraging vertical growth. Providing that coral growth is higher or equal to the sedimentation rate, corals will persist and a height differential will develop between coral colonised areas and the surrounding seabed.

This development process may have been proceeding for several thousand years although the Moira Mounds are still at the early start-up or incipient bank development phase as propsed by Henriet et al. (2003) and reviewed in Roberts et al (2006; 2009).

The location of the two main areas of Moira Mound development are between and westward (downslope) of the two coral carbonate mound chains. To the east of the Moira Mounds, contemporary coral growth on the coral carbonate mounds is limited and the banks are classified as "dormant" (Foubert et al., 2005; Huvenne et al., 2005) although this was obviously not the case in the geological past. This upslope area also coincides with only a few examples of Moira Mounds. Presently, the "dormant" bank summits sit within the Eastern North Atlantic Water watermass, whereas the Moira Mounds and "active" coral carbonate mounds in deeper water downslope sit within the Mediterranean Outflow Water (MOW). The specific properties of this water mass appear to be important for the vitality of the cold-water corals in this area. Dullo et al. (2008) suggest that the specific water mass property is water density $\left(\sigma_{\theta}\right)$ noting that in the NE Atlantic Lophelia pertusa always grows in watermass with a $\sigma_{\theta}$ value of 27.35 to 27.65 $\mathrm{kg} \mathrm{m}^{-3}$ and further postulate that this may be because of a water density control on larval dispersion.

The previously unnoted observation that most of the Moira Mounds (143 out of 256) occur west of the "active" coral carbonate mounds suggests that there is westward (downslope) migration in the optimal environment for cold-water coral growth in this region durinmg the Holocene.

The suggestion by De Mol et al. (2005) and Huvenne et al. (2005) that clusters of Moira Mounds may, over geological time periods, coalesce and vertically grow to form coral 
carbonate mounds is re-emphasised here. Figure 8 shows for the first time areas where clusters of Moira Mounds of comparable size to the footprint of the coral carbonate mounds exist. Were these to form the next generation of Belgica Mounds, an additional coral carbonate mound will be added to the existing "dormant" chain, new coral carbonate mounds will form between the two existing chains and an additional western downslope chain will be added. Perhaps more significantly, as far as can be ascertained from seismic evidence (De Mol et al., 2003, 2007) this is the only time that there has been another start-up phase in the Belgica mound province. Whether this means that other unsuccessful phases of Moira Mound development have been eroded away or whether we are experiencing unique bank formation conditions today cannot be determined with certainty. 


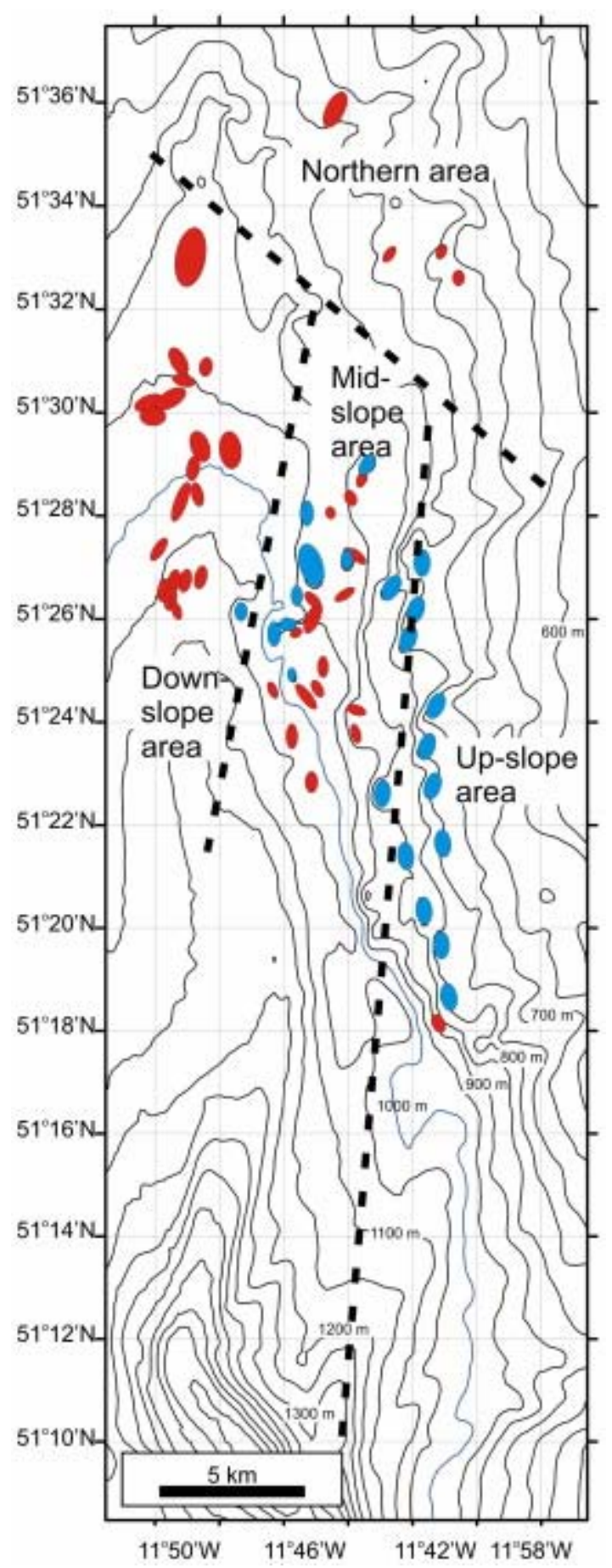

Fig. 8. Moira Mound clusters (red ovals) indicating the likely location of future coral carbonate mounds. Contemporary coral carbonate mounds are blue. Moira Mound clusters (grey ovals) indicating the likely location of future coral carbonate mounds. Contemporary coral carbonate mounds are black. 


\section{Conclusions}

Based on geophysical, biological, sedimentological and visual observations, the Moira Mounds can be classified as cold-water coral banks or scleractinian spaced cluster macroreefs (sensu Riding, 2002). They exist in areas of active bedload sand transport that accumulates into banks due to the hydrodynamic effects caused by the presence of coral colonies. 256 examples have been mapped. New geophysical interpretations show that banks occur as isolated features and in clusters where continued growth may cause them to coalesce. It is postulated that such a process, over time, may result in coral carbonate mounds, contemporary examples of which exist nearby.

Within the Belgica mound province, coral carbonate mounds are aligned in two chains, the westernmost of which is densely covered by cold-water coral whereas the easternmost is not. The Moira Mounds exist between the two chains and further to the west again at water depths where contemporary cold-water corals grow. This suggests a further westward, downslope migration of the suitable environment for cold-water coral mound formation and potentially the establishment over time of a new chain.

\section{Acknowledgements}

The following are acknowledged for their assistance with the collection and processing of $100 \mathrm{kHz}, 410 \mathrm{kHz}$ and TOBI side-scan sonar data, video footage, sediment and box core samples: the officers, scientists and crew of the RRS Discovery 248, RV Pelagia Cruise 197, N/O Atalante CARACOLE and Polarstern ARKXIX/3a cruises, the VICTOR 6000 dive team and Dr. Tim Le Bas (NOC).

This paper uses data and survey results acquired during a project funded by EASSS undertaken on behalf of the Porcupine Studies Group (PSG) of the Irish Petroleum Infrastructure Programme Group 3. The PSG comprises: Agip, Chevron, Elf, Enterprise, Marathon, Phillips, Statoil and the Petroleum Affairs Division of the Department of Marine and Natural Resources. $100 \mathrm{kHz}$ and $410 \mathrm{kHz}$ side-scan sonar was funded under the EU FP5 projects ACES and ECOMOUND.

L.-A. Henry would like to thank the following people for their valuable taxonomic expertise in assisting with faunal identifications: Tim Beck (molluscs), Peter Hayward (bryozoans), Maarten Raes (nematodes) and Peter Schuchert (scyphozoans). K. Olu thank J. Vacelet (sponges) and P. Lorance (fishes) for their identifications, and J.-C. Caprais for methane measurements.

Funding for L.-A. Henry and V.A.I. Huvenne provided by Marie Curie Fellowships from the European Community Sixth Framework Programme. A. Foubert was funded through a fellowship of the FWO-Flanders (Belgium). 


\section{References}

Akhmetzhanov, A.M., Kenyon, N.H., Ivanov, M.K., Wheeler, A.J., Shashkin, P.V., van Weering, T.C.E., 2003b. Giant carbonate mounds and current-swept seafloors on the slopes of the southern Rockall Trough, in: Mienert, J., Weaver, P. (Eds.) European Margin Sediment Dynamics: Side - Scan Sonar and Seismic Images. Springer-Verlag, Berlin, pp. 203-209.

Bett, B.J., Billett, D.S.M., Masson, D.G., Tyler, PA., 2002. RRS Discovery Cruise 248 - A multi-disciplinary study of the environment and ecology of deep-water coral ecosystems and associated seabed facies and features (The Darwin Mounds, Porcupine Bank and Porcupine Seabight), Southampton Oceanography Centre, Cruise Report 36, 55pp.

Beyer, A., Schenke, H.W., Klenke, M., Niederjasper, N., 2003. High resolution bathymetry of the eastern slope of the Porcupine Seabight. Marine Geology 198, 27-54. Cairns, S.D., 1992. Worldwide distribution of the Stylasteridae (Cnidaria: Hydrozoa). Scientia Marina 56, 125-130.

Costello, M.J., McCrea, M., Freiwald, A., Lundälv, T., Jonsson, L., Bett, B.J., van Weering, T.C.E., de Haas, H., Roberts J.M., Allen, D., 2005. Role of cold-water Lophelia pertusa coral reefs as fish habitats in the NE Atlantic, in: Freiwald, A., Roberts, J.M. (Eds.), Cold-water corals and Ecosystems. Springer-Verlag, Berlin Heidelberg, pp. 771805.

de Haas, H., Huvenne, V., Wheeler, A., Shipboard Scientific Crew, 2002. M2002 Cruise Report (R.V. Pelagia Cruise 64PE197): A TOBI Side Scan Sonar Survey of Cold Water Coral Carbonate Mounds in the Rockall Trough and Porcupine Sea Bight. 21 June - 14 July 2002. Texel-Southampton-Galway. NIOZ, Texel.

de Haas, H., Mienis, F., Frank, N., Richter, T.O., Steinacher, R., de Stigter, H., van de Land, C., van Weering, T.C.E., 2009. Morphology and sedimentology of (clustered) coldwater coral mounds at the south Rockall Trough margins, NE Atlantic Ocean. Facies 55, $1-26$.

De Mol., B., Henriet, J.-P., Canals, M., 2005. Development of coral banks in Porcupine Seabight: do they have Mediterranean ancestors, in: Freiwald, A., Roberts, J.M. (Eds.), Cold-water corals and Ecosystems. Springer-Verlag, Berlin Heidelberg, pp. 515-533.

De Mol, B., Kozachenko, M., Wheeler, A., Alvares, H., Henriet, J.P., Le Roy, O., 2007. Thérèse Mound: a case study of coral bank development in the Belgica Mound Province, Porcupine Seabight. International Journal of Earth Science 96, 103-120.

De Mol, B., Van Rensbergen, P., Pillen, S., Van Herreweghe, K., Van Rooij, D., McDonnell, A., Huvenne, V., Ivanov, M., Swennen, R., Henriet, J.P., 2002. Large deepwater coral banks in the Porcupine Basin, southwest Ireland. Marine Geology 188, 193231.

Dorschel B., Hebbeln D., Foubert A., White M., Wheeler A.J., 2007a. Hydrodynamics and cold-water coral facies distribution related to recent sedimentary processes at Galway Mound west of Ireland. Marine Geology 244, 184-195.

Dorschel, B., Hebbeln, D., Rüggeberg, A., Dullo, W.-C., 2007b. Carbonate budget of a cold-water coral carbonate mound: Propeller Mound, Porcupine Seabight. International Journal of Earth Science 96, 73-83.

Dorschel, B., Hebbeln, D., Rüggeberg, A., Dullo, W.-C., Freiwald, A., 2005. Growth and erosion of a cold-water coral covered carbonate mound in the Northeast Atlantic during the Late Pleistocene and Holocene. Earth and Planetary Science Letters 233, 33-44. 
Dorschel, B., Wheeler, A.J., Huvenne, V.A.I., de Haas, H., 2009. Cold-water coral mounds in an erosive environmental setting: TOBI side-scan sonar data and ROV video footage from the northwest Porcupine Bank, NE Atlantic. Marine Geology 264, 218-229.

Dullo, W.-C., Flögel, S., Rüggeberg, A., 2008. Cold-water coral growth in relation to the hydrography of the Celtic and Nordic European continental margin. Marine Ecology Progress Series 371, 165-176.

Fabri, M.C., Galéron, J., Larour, M., Maudire, G., 2006. Combining the Biocean database for deep-sea benthic data with the online Ocean Biogeographic Information System. Marine Ecology Progress Series 316, 215-224.

Fagan, B.M. (2000). The Little Ice Age: how climate made history. Basic Books, New York.

Foubert, A., Beck, T., Wheeler, A.J., Opderbecke, J., Grehan, A., Klages, M., Thiede, J., Henriet, J.P., the Polarstern ARK-XIX/3a shipboard party, 2005. New view of the Belgica Mounds, Porcupine Seabight, NE Atlantic: Preliminary Results from the Polarstern ARKXIX/3a ROV cruise, in: Freiwald, A., Roberts, J.M. (Eds), Cold-water corals and Ecosystems. Springer-Verlag, Berlin Heidelberg. pp. 403-415.

Foubert, A., Huvenne, V.A.I., Wheeler, A.J., Kozachenko, M., Opderbecke, J., Henriet, J.-P., this issue. The Moira Mounds, small cold-water coral banks in the Porcupine Seabight, NE Atlantic: Part B - high-resolution multibeam ROV bathymetric mapping and sediment dynamics. Marine Geology, this issue.

Frank, N., Lutringer, A., Paterne, M., Blamart, D., Henriet, J.-P., van Rooij, D., van Weering, T.C.E., 2005. Deep-water corals of the northeastern Atlantic margin: carbonate mound evolution and upper intermediate water ventilation during the Holocene, in: Freiwald, A., Roberts, J.M. (Eds), Cold-water corals and Ecosystems. Springer-Verlag, Berlin. pp.113-133.

Frederiksen, R., Jensen, A., Weesterberg, H., 1992. The distribution of the scleractinian coral Lophelia pertusa around the Faroes Islands and the relation to internal tidal mixing. Sarsia 77, 157-171.

Freiwald, A., Fosså, J. H., Grehan, A., Koslow, T., Roberts, J.M., 2004. Cold-Water Coral Reefs. UNEP-WCMC, Cambridge, United Kingdom, pp. 84.

Freiwald, A., Hühnerbach, V., Lindberg, B., Wilson, J.B., Campbell, J., 2002. The Sula Reef complex, Norwegian Shelf. Facies 47, 179-200.

Freiwald A., Roberts, J.M. (Eds.), 2005. Cold-water Corals and Ecosystems. SpringerVerlag, Berlin, Heidelberg, 1243 pp.

Freiwald, A. Wilson, J.B., Henrich, R., 1999. Grounded Pleistocene icebergs shape recent deep-water coral reefs. Sedimentary Geology 125, 1-8.

Grasmueck, M., Eberli, G. P., Viggiano, D. A., Correa, T., Rathwell, G., Luo, J., 2006. Autonomous underwater vehicle (AUV) mapping reveals coral mound distribution, morphology, and oceanography in deep water of the Straits of Florida, Geophysical Research Letters 33, L23616.

Hargreaves, P.M., 1984. The distribution of Decapoda (Crustacea) in open ocean near bottom over an adjacent slope in the Nothern North-east Atlantic Ocean during autumn 1979. Journal of the Marine Biological Association of the United Kingdom 64, 829-857.

Henriet, J.P., De Mol, B., Pillen, S., Vanneste, M., van Rooij, D., Versteeg, W., Croker, P.F., Shannon, P.M., Unnithan, V., Bouriak, S., Chachkine, P., the Porcupine Belgica 97 Shipboard Party, 1998. Gas hydrate crystals may help build coral reefs. Nature 391, 648-649.

Henriet, J.-P., Guidard, S., ODP „Proposal 573" Team, 2003. Carbonate mounds as a possible example for microbial activity in geological processes, in: Wefer, G., Billett, D., 
Hebbeln, D., Jørgensen, B.B., Schlüter, M., van Weering, T.C.E. (Eds.), Ocean Margin Systems, Spinger-Verlag, Berlin Heidelberg, pp. 439-455.

Henry, L.-A., Roberts, J.M., 2007. Biodiversity and ecological composition of macrobenthos on cold-water coral mounds and adjacent off-mound habitat in the bathyal Porcupine Seabight, NE Atlantic. Deep-Sea Research I, 54, 654-672.

Hovland, M., 2008. Deep-water coral reefs: unique biodiversity hot-spots. Springer Praxus, Chicester, UK., 274 pp.

Hovland, M., Croker, P.F., Martin, M., 1994. Fault-associated seabed mounds (carbonate knolls?) off western Ireland and north-west Australia. Marine and Petroleum Geology. 11, 232-246.

Hovland, M., Mortensen, P.B., Brattegard, T., Strass, P., Rokoengen, K., 1998. Ahermatypic coral banks off mid-Norway: evidence for a link with seepage of light hydrocarbons. Palaios 13, 189-200.

Hovland, M., Thomsen, E., 1997. Cold-water corals - are they hydrocarbon seep related? Marine Geology 137, 159-164.

Hughes, J.A., Gooday, A.J., 2002. The distribution of the xenophyophore Syringammina fragilissima in the northeast Atlantic and its influence on the diversity of bathyal foraminiferal assemblages. Newsletter of Micropalaeontology 66, 15-16.

Huvenne, V.A.I., Beyer, A., de Haas, H., Dekindt, K., Henriet, J.P., Kozachenko, M., Olu-Le Roy, K., Wheeler, A., the TOBI/Pelagia 197 and CARACOLE cruise

participants, 2005. The seabed appearance of different coral bank provinces in the Porcupine Seabight, NE Atlantic: results from sidescan sonar and ROV seabed mapping, in: Freiwald, A., Roberts, J.M. (Eds), Cold-water corals and Ecosystems, Springer-Verlag, Berlin Heidelberg. pp. 535-569.

Huvenne, V.A.I., Blondel, P., Henriet, J.-P., 2002. Textural analyses of sidescan sonar imagery from two mound provinces in the Porcupine Seabight. Marine Geology 189, 323-341.

Huvenne, V.A.I., Masson, D.G., Wheeler, A., 2009. Sedimentary dynamics of a sandy contourite: the sedimentary context of the Darwin cold-water coral mounds, Northern Rockall Trough. International Journal of Earth Science 98, 865-884.

Jensen, A., Frederiksen, R., 1992. The fauna associated with the bank-forming deepwater coral Lophelia pertusa (Scleractinia) on the Faroe Shelf. Sarsia, 77, 53- 69.

Kano, A., Ferdelman, T.G., Williams, T., Henriet, J.-P., Ishikawa, T., Kawagoe, N., Takashima, C., Kakizaki, N., Abe, K., Sakai, S., Browning, E.L., Li, X., IODP Expedition 307 scientists, 2007. Age constraints on the origin and growth history of a deep-water coral mound in NE Atlantic drilled during Integrated Ocean Drilling Program Expedition 307. Geology 35, 1051-1054.

Kenyon, N.H., Akhmetzhanov, A.M., Wheeler, A.J., van Weering, T.C.E., de Haas, H., Ivanov, M.K., 2003. Giant carbonate mud mounds in the southern Rockall Trough. Marine Geology 195, 5-30.

Kenyon, N.H, Ivanov, M.K., Akhmetjanov, A.M., 1998. Cold Water Carbonates Mounds and Sediment Transport on the NE Atlantic Margin: Preliminary Results of Geological and Geophysical Investigations during the TTR-7 Cruise of the R/V Professor Logachev Co-operation with CORSAIRES and ENAMII programs. Intergovernmental Oceanographic Commission Technical Series, 52. IOC- UNESCO, Paris, 179 pp.

Klages, M., Thiede, J., Foucher, J-P., 2004. The Expedition 849 ARKTIS XIX/3 of the Research Vessel POLARSTERN in 2003. Reports of Legs 3a, 3b and 3c. Reports on Polar and Marine Research 488, 355 pp.

Kozachenko, M., 2005. Present and Past Environments of the Belgica Mounds (deep water coral carbonate mounds), Eastern Porcupine Seabight, North East Atlantic. Unpublished PhD Thesis, University College Cork, Ireland. 
Le Bas, T., Hühnerbach, V., 1999. P.R.I.S.M. Processing of Remotely-sensed Imagery for Seafloor Mapping Operators Manual Version 3.1. Southampton Oceanography Centre, UK.

Le Guilloux, E., Olu, K., Bourillet, J.F., Savoye, B., Iglésias, S.P., Sibuet, M. (2009) First observations of deep-sea coral reefs along the Angola margin. Deep Sea Research II 56, 2394-23403..

Lindberg, B., Berndt, C., Meinert, J., 2007. The Fugløy Reefs on the Norwegian- Barents Continental Margin: Cold-water Corals at $70^{\circ} \mathrm{N}$, their acoustic signature, geologic, geomorphologic and oceanographic setting. International Journal of Earth Sciences 96, 201- 213.

Martin, D., Britayev, T.A., 1998. Symbiotic polychaetes: review of known species. Oceanography and Marine Biology. An Annual Review 36, 217-340.

Masson, D.G., Bett, B.J., Billett, D.S.M., Jacobs, C.L., Wheeler, A.J., Wynn, R.B., 2003. The origin of deep-water, coral-topped mounds in the northern Rockall Trough, Northeast Atlantic. Marine Geology 192, 215-237.

Messing, C.G., Neumann, A.C., Lang, J.C., 1990. Biozonation of deep-water lithoherms and associated hardgrounds in the northeasterm Straits of Florida. Palaois 5, 15-33.

Mienis, F., van Weering, T., de Haas, H., de Stigter, H., Huvenne, V., Wheeler. A., 2006. High-resolution TOBI images and seismic profiles of a carbonate mound province at the SW Rockall Trough Margin, NE Atlantic. Marine Geology 233, 1-19.

Mortensen, P.B., Hovland, M., Brattegard, T., Farestveit, R., 1995. Deep water bioherms of the scleractinian coral Lophelia pertusa (L.) at $64^{\circ} \mathrm{N}$ on the Norwegian shelf: structure and associated fauna, Sarsia 80, 145-158.

Mortensen, P.B., Hovland, M.T., Fossa, J.H., Furevik, D.M., 2001. Distribution, abundance and size of Lophelia pertusa coral reefs in mid-Norway in relation to seabed characteristics. Journal of the Marine Biological Association of the United Kingdom 81, 581-597.

New, A.L., Smythe-Wright, D., 2001. Aspects of the circulation in the Rockall Trough. Continental Shelf Research 21, 777-810.

Olu-Le Roy, K., Caprais, J.-C., Crassous, P., Dejonghe, E., Eardley, D., Freiwald, A., Galeron, J., Grehan, A., Henriet, J-P., Huvenne, V., Lorance, P., Noel, P., Opderbecke, J., Pitout, C., Sibuet, M., Unnithan, V., Vacelet, J., Van Weering, T., Wheeler, A., Zibrowius, H., 2002. CARACOLE Cruise Report. 30/07/2001 (Cobh) - 15/08/2001

(Foynes) N/O L'Atalante \& ROV VICTOR, Vols. 1 \& 2. Unpublished Report, IFREMER, Brest.

Pingree, R.D., LeCann, B., 1990. Structure, strength and seasonality of the slope current in the Bay of Biscay region. Journal of the Marine Biological Association of the United Kingdom 70, 857-885.

Reed, J.K., Weaver, D.C., Pomponi, S.A., 2006. Habitat and fauna of deep-water Lophelia pertusa coral reefs off the southeastern U.S.: Blake Plateau, Straits of Florida, and Gulf of Mexico. Bulletin of Marine Science 78, 343-375.

Rice, A.L., Billett, D.S.M., Thurston, M.H., Lampitt, R.S., 1991. The Institute of Oceanographic Sciences Biology Programme in the Porcupine Seabight: background and general introduction. Journal of the Marine Biological Association of the United Kingdom 71, 281-310.

Riding, R., 2002. Structure and composition of organic reefs and carbonate mud mounds: concepts and categories. Earth-Science Reviews 58, 163-231.

Roberts, J.M., 2002. The occurrence of the coral Lophelia pertusa and other conspicuous epifauna around an oil platform in the North Sea. Underwater Technology 25, 83-91. 
Roberts, J. M., 2005. Reef-aggregating behaviour by symbiotic eunicid polychaetes from cold-water corals: do worms assemble reefs? Journal of the Marine Biological Association of the United Kingdom, 85, 813-819.

Roberts, J.M., Henry, L.-A., Long, D., Hartley, J.P., 2008. Cold-water coral reef frameworks, megafaunal communities and evidence for coral carbonate mounds on the Hatton Bank, north east Atlantic. Facies 54, 297-316.

Roberts, J.M., Peppe, O.C., Dodds, L.A., Mercer, D.J., Thomson, W.T., Gage, J.D., Meldrum, D.T., 2005. Monitoring environmental variability around cold-water coral reefs: the use of a benthic photolander and the potential of seafloor observatories. in: Freiwald, A., Roberts, J.M. (Eds), Cold-water corals and Ecosystems, Springer-Verlag, Berlin Heidelberg. pp. 483-502.

Roberts, J.M., Wheeler, A.J., Freiwald, A., 2006. Reefs of the deep: the biology and geology of cold-water coral ecosystems. Science 312, 543-547.

Roberts, J.M., Wheeler, A.J., Cairns, S., Freiwald, A., 2009. Cold-water corals: the biology and geology of deep-sea coral habitats. Cambridge University Press,

Cambridge.

Rogers, A.D., 1999. The biology of Lophelia pertusa (Linnaeus 1758) and other deep water reef-forming corals and impacts from human activity. International Review of Hydrobiology 84, 315-410.

Rüggeberg, A., Dorschel, B., Dullo, W.-C., Hebbeln, D., 2005. Sedimentary patterns in the vicinity of a carbonate mound in the Hovland Mound Province, northern Porcupine Seabight, in: Freiwald, A., Roberts, J.M. (Eds), Cold-water corals and Ecosystems, Springer-Verlag, Berlin Heidelberg, pp. 87-112.

Rüggeberg, A., Dorschel, B., Dullo, W.-C., Hebbeln, D., 2007. Environmental changes and growth history of a cold-water carbonate mound (Propeller Mound, Porcupine Seabight). International Journal of Earth Science 96, 57-72.

Sakai, S., Kano, A., Abe, K., 2009. Origin, glacial-interglacial responses, and the controlling factors of a cold-water coral mound in the NE Atlantic, Palaeoceanography 24, PA2213, doi:10.1029/2008PA001695.

Sibuet, M., Olu, K., 1998. Biogeography, biodiversity and fluid dependence of deep sea cold-seep communities at active and passive margins. Deep-sea Research II 45, 517567.

Tendal, O.S., Thorsen, M.S., Zibrowius, H., 2005. Stylasteridae (Cnidaria: Hydrozoa) of the Faroe region. BIOFAR Proceedings, 2005, pp. 63-76.

Titschack, J., Thierens, M., Dorschel, B., Schulbert, C., Freiwald, A., Kano, A., Takashima, C., Kawagoe, N., Li, X., 2009. Carbonate budget of a cold-water coral mound (Challenger Mound, IODP Exp. 307). Marine Geology 259, 36-46.

Van Aken, H.M., Becker, G., 1996. Hydrography and through-flow in the north eastern North Atlantic; the NANSEN project. Progress in Oceanography 38, 297-346.

Van Rooij, D., Blamart, D., Richter, T., Wheeler, A., Kozachenko, M., J.-P. Henriet, 2007. Quaternary drift sediment dynamics in the Belgica mound province, Porcupine Seabight: a multidisciplinary approach. International Journal of Earth Science 96, 121-140.

Van Rooij, D., De Mol, B., Huvenne, V., Ivanov, M., Henriet, J.-P., 2003. Seismic evidence of current-controlled sedimentation in the Belgica mound province, upper Porcupine slope, southwest of Ireland. Marine Geology 195, 31-53.

van Weering, T.C.E., De Haas, H., Akhmetzanov, A.M., Kenyon, N.H., 2003. Giant carbonate mounds along the Porcupine and SW Rockall Trough Margins, in: Mienert, J., Weaver, P. (Eds.), European Margin Sediment Dynamics: Side - Scan Sonar and Seismic Images. Springer-Verlag, Berlin Heidelberg. pp. 211-216.

Wenner, E.L., Barans, C.L., 2001. Benthic habitats and associated fauna of the upperand middle continental slope near the Charleston Bump, in: Sedberry, G.R. (Ed.), Island 
in the Stream: oceanography and fisheries of the Charleston Bump. American Fisheries Society Symposium 25, Bethesda, MD, p. 161-175.

Wheeler, A.J., Beck, T., Thiede, J., Klages, M., Grehan, A. Monteys, F.X., Polarstern ARK XIX/3a Shipboard Party, 2005a. Deep-water coral mounds on the Porcupine Bank, Irish margin: preliminary results from Polarstern ARK-XIX/3a ROV cruise, in: Freiwald, A., Roberts, J.M. (Eds), Cold-water corals and Ecosystems, Springer-Verlag, Berlin Heidelberg. pp. 393-402.

Wheeler, A.J., Bett, B.J., Billett, D.S.M., Masson, D. G., Mayor, D., 2005b. The impact of demersal trawling on NE Atlantic deep-water coral habitats: the case of the Darwin Mounds, UK, in: Thomas, J., Barnes, P. (Eds.), Benthic Habitats and the Effects of Fishing. America Fisheries Society, Bethesda, Maryland, USA., p.807-817.

Wheeler, A.J., Bett, B.J., Billett, D.S.M., Masson, D.G., Scientific Party, Officers and Crew of Discovery 248, 2000. Very high resolution side-scan mapping of deep water coral mounds: surface morphology and processes affecting growth Abstract: AGU Fall Meeting 2000, December 15-19/2000, San Francisco, California, EOS, American Geophysical Union 81(48), F638.

Wheeler, A.J., Beyer, A., Freiwald, A., de Haas, H., Huvenne, V.A.I., Kozachenko, M., Olu-Le Roy, K., 2007. Morphology and Environment of Deep-water Coral Mounds on the NW European Margin. International Journal of Earth Science 96, 37-56.

Wheeler, A., de Haas, H., Huvenne, V., 2003. The Porcupine and Rockall Margin TOBI Regional Side-Scan Survey: PSG 01/002 Final Report. University College Cork, Cork.

Wheeler, A.J., Kozachenko, M., Beyer, A., Foubert, A., Huvenne, V.A.I., Klages, M., Masson, D.G., Olu-Le Roy, K., Thiede, J., 2005c. Sedimentary processes and carbonate mounds in the Belgica mound province, Porcupine Seabight, NE Atlantic, in: Freiwald, A., Roberts, J.M. (Eds), Cold-water corals and Ecosystems. Springer-Verlag, Berlin Heidelberg. pp. 571-603.

Wheeler, A.J., Kozachenko, M., Masson, D.G., Huvenne, V.A.I., 2008. The influence of benthic sediment transport on cold-water coral bank morphology and growth: the example of the Darwin Mounds, NE Atlantic. Sedimentology 55, 1875-1887.

White, M., 2007. Benthic dynamics at the carbonate mound regions of the Porcupine Sea Bight continental margin. International Journal of Earth Science 96, 1-9.

White, M., Mohn, C., de Stigter, H., Mottram, G., 2005. Deep-water coral development as a function of hydrodynamics and surface productivity around submarine banks of the Rockall Trough, NE Atlantic, in: Freiwald, A., Roberts, J.M. (Eds), Cold-water corals and Ecosystems, Springer-Verlag, Berlin Heidelberg. pp. 503-514.

White, M., Roberts, J.M., van Weering, T.C.E., 2007. Do bottom-intensified diurnal tidal currents shape the alignment of carbonate mounds in the NE Atlantic? Geo-Marine Letters 27, 391-397.

Williams, T., Kano, A., Ferdelman, T., Henriet, J.-P., Abe, K., Andres, M.S., Bjerager, M., Browning, E.L., Cragg, B.A., De Mol, B., Dorschel, B., Foubert, A., Frank, T.D., Fuwa, Y., Gaillot, P., Gharib, J.J., Gregg, J.M., Huvenne, V.A.I., Léonide, P., Li, X., Mangelsdorf, K., Tanaka, A., Monteys, X., Novosel, I., Sakai, S., Samarkin, V.A., Sasaki, K., Spivack, A.J., Takashima, C., Titschack, J., 2006. Cold-water coral mounds revealed. EOS 87, 525-526. 